\title{
PAISAGEM COMO INFRAESTRUTURA DE TRATAMENTO DAS ÁGUAS URBANAS
}

\author{
RAMÓN STOCK Bonzı* \\ * Professor de jardinagem, especialista em meio ambiente e sociedade pela Fundação Escola de Sociologia \\ e Política de São Paulo, aluno do curso de pós-graduação "Arquitetura da Paisagem" (Senac) e mestrando \\ na FAUUSP na área de concentração Paisagem e Ambiente. \\ e-mail: rsb@usp.br
}

\begin{abstract}
RESUMO
Este trabalho investiga o uso da vegetação no tratamento de esgotos, efluentes e águas residuais. Apresenta-se a situação de nossos corpos d'água e revela-se como ecossistemas naturais de áreas úmidas colaboram com a manutenção de sua qualidade. São observados os mecanismos principais que possibilitam que os sistemas de tratamento e polimento da água por meio do uso de vegetação proporcionem serviços ambientais importantes para os assentamentos humanos. E por fim, é apontado como o uso da vegetação no tratamento de água é capaz de criar paisagens multifuncionais que desempenham funções ligadas ao lazer, à educação ambiental e à geração de renda.
\end{abstract}

Palavras-chave: Alagado Construído - Infraestrutura Verde - Metabolismo Urbano Tratamento de Efluentes - Biomimética - Infraestrutura paisagística.

\section{LANDSCAPE AS INFRASTRUCTURE FOR URBAN WATER TREATMENT}

\begin{abstract}
This paper investigates the vegetation use for treatment of sewage, effluents and wastewater. It shows the status of our water bodies and reveals how the natural ecosystems of wetlands collaborate with maintaining its quality. It is observed the main mechanisms that enable systems of treatment and polishing of water, through the use of vegetation, provide important ecosystem services for human settlements. Finally, it is pointed out how the use of vegetation in water treatment is capable to create multifunctional landscapes that perform functions related to recreation, environmental education and income generation.
\end{abstract}

Keywords: Built Wetland - Green Infrastructure - Urban Metabolism - Wastewater Treatment - Biomimicry - Infrastructure landscape. 


\section{INTRODUÇÃO}

\section{Consumo e serviços ambientais na cidade}

Segundo dados do Governo do Estado de São Paulo, no Brasil, $80 \%$ da população já vive em áreas urbanas (SVMA, 2010, p.14). No entanto, apesar da consolidação do hábitat urbano, o adensamento populacional não foi acompanhado da necessária expansão das redes de infraestrutura e serviços. Isso amplifica os efeitos negativos que decorrem do fato de que as nossas cidades, sob o ponto de vista ecológico, são ecossistemas incompletos, conforme explica FRANCO:

A cidade, bem como seu sentido ampliado para a área metropolitana, pode ser classificado, na visão ecológica, com um sistema incompleto ou heterotrófico, dependente de grandes áreas externas a ele para a obtenção de energia, alimentos, fibras, água e outros materiais. No entanto a mesma difere de um ecossistema heterotrófico natural, tal como um recife de ostras, por apresentar um metabolismo muito mais intenso por unidade de área. (2001, p.64).

Em outras palavras, a cidade é um ecossistema incompleto porque não consegue prover serviços em quantidade e qualidade suficiente para os seres vivos - incluindo os humanos - que nela vivem. Alguns desses serviços podem ser obtidos da própria natureza. São os serviços ambientais ou serviços ecossistêmicos, ou seja, os benefícios que as pessoas obtêm dos ecossistemas. Segundo o CONSELHO DE AVALIAÇÃO ECOSSISTÊMICA DO MILÊNIO (Figura 1) os serviços ecossistêmicos incluem:

serviços de abastecimento, como alimentos e água; serviços de regulação, como inundações e controle de enfermidades; serviços culturais, como benefícios espirituais, recreativos e culturais; e serviços de apoio, como ciclo de nutrientes, que mantém a vida na Terra. (2005, p. 95) 


\section{Produção \\ Bens produzidos ou \\ aprovisionados pelos \\ ecossistemas \\ - alimento \\ - água doce \\ - lenha \\ - fibra \\ - bioquímicos \\ - recursos genéticos}

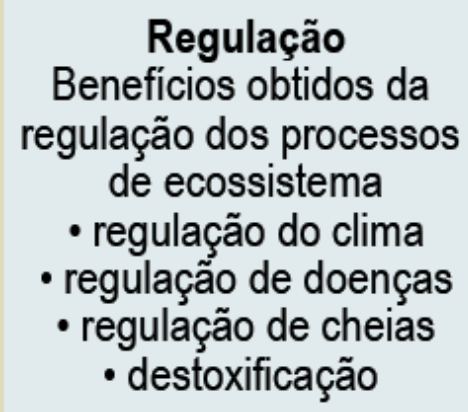

Regulação

Benefícios obtidos da regulação dos processos

de ecossistema

- regulação do clima

- regulaçẩo de doenças

- regulação de cheias

- destoxificação

Culturais Benefícios não materiais obtidos dos ecossistemas

- espiritual

- recreativo

- estético

- inspiração

- educativo

- simbólico

\section{Suporte}

Serviços necessários para a produção de todos os outros serviços

- Formação do solo

- Ciclos dos nutrientes

- Produtividade primária

\section{Biodiversidade}

Figura 1 - Quadro de serviços ecossistêmicos desempenhados pela natureza. (Aqui produção é sinônimo de abastecimento e suporte de apoio.) Fonte: Millennium Ecosystem Assessment - Avaliação Portuguesa. Disponível em: <http://ecossistemas.org/ficheiros/Folheto-Port.pdf>. Acessado em 04 de abril de 2013.

Embora essa definição dê margem ao argumento de que a cidade é extremamente bem sucedida no provimento de serviços culturais - ainda que nunca se questione a qualidade deles ${ }^{1}$ - ela é geralmente deficitária no provimento dos demais serviços, principalmente quando se apresenta em sua forma hiperbólica, a metrópole.

O CONSELHO DE AVALIAÇÃO ECOSSISTÊMICA DO MILÊNIO esclarece que isso ocorre porque "as intervenções humanas podem aumentar alguns serviços, embora muitas vezes isso ocorra à custa de outros serviços". (2005, p. 110)

\footnotetext{
${ }^{1}$ Comumente negligencia-se o fato de que nem tudo que é cultura "só pode fazer o bem além de fazer bem", como explica COELHO (2008, p. 11)
} 
O recente relatório "A Pegada Ecológica de São Paulo Estado e Capital" ${ }^{2}$, da WWF, relata o custo desta hiperespecialização urbana. $O$ estudo apresenta dados impressionantes acerca das áreas que São Paulo (cidade e estado) precisaria ter para produzir todos os bens e serviços oriundos de recursos naturais renováveis, bem como as áreas necessárias para absorver suas respectivas emissões de CO2. São eles:

O estado de São Paulo necessitaria de uma área de $1.658 .571 \mathrm{Km}^{2}$, quase sete vezes a área oficial do estado. A cidade de São Paulo precisaria, neste caso, de uma área de $595.939 \mathrm{Km}^{2}$ para ser autossuficiente, considerando que seu consumo atual é mais de 390 vezes a área total do município. (Idem, p. 64)

Segundo o estudo,

A Pegada Ecológica média do estado de São Paulo é de 3,52 hectares globais per capita e de sua capital, a cidade de São Paulo, 4,38 gha/cap. Isso significa que, se todas as pessoas do planeta consumissem de forma semelhante aos paulistas, seriam necessários quase dois planetas para sustentar esse estilo de vida. Se vivessem como os paulistanos, quase dois planetas e meio. (2012, p. 18)

Para se ter uma ideia da pressão que a cidade de São Paulo ${ }^{3}$ exerce sobre os ecossistemas é necessário contextualizar que a "média mundial da Pegada Ecológica é de 2,7 hectares globais por pessoa, enquanto que a biocapacidade disponível para cada ser humano é de apenas 1,8 hectare global". (Idem, p. 50)

A velocidade desse gigantesco metabolismo urbano reflete-se na produção de resíduos, incluindo-se aí o tratamento de esgoto. O resultado é um quadro preocupante, caracterizado por precarização das condições de vida da população, mortalidade infantil e degradação ambiental das cidades e dos ecossistemas, o que evidentemente autoriza considerar a maioria das urbes brasileiras, notadamente a região metropolitana de São Paulo, como não sustentável.

\footnotetext{
2 "A Pegada Ecológica mede a quantidade de terra biologicamente produtiva e de área aquática necessárias para produzir os recursos que um indivíduo, população ou atividade consome para absorver os resíduos que gera, considerando a tecnologia e o gerenciamento de recursos prevalecentes". (WWF, 2012, p. 100)

${ }^{3}$ São Paulo, a maior cidade da América Latina, possui uma população de 10,8 milhões de habitantes (p. 11) e sua região metropolitana, embora ocupe um milésimo do território brasileiro, abriga $10 \%$ da população (p.13). (WWF, 2012)
} 
A reversão do quadro descrito acima passa necessariamente pela análise de questões relativas ao saneamento básico e pelo enfrentamento da degradação das reservas de água doce.

Sendo assim, urge a identificação, a compreensão e o fomento de propostas não convencionais de se lidar com as questões relativas ao tratamento de águas das cidades.

Neste sentido, destacam-se os sistemas construídos que usam vegetação no tratamento de água. Estes, além de terem sua eficiência técnica e viabilidade econômica confirmada na literatura aqui referenciada, podem contribuir significativamente para a conscientização de que os assentamentos humanos acarretam impactos sobre os ecossistemas em geral, e sobre a qualidade da água, em particular. E sinalizam que sistemas biomiméticos, isto é, sistemas sintéticos inspirado na natureza, podem colaborar significativamente na constituição de uma infraestrutura verde ${ }^{4}$ urbana que tornará as nossas cidades mais verdes e sustentáveis.

\section{O CICLO DA ÁGUA NOS ASSENTAMENTOS HUMANOS}

\section{As reservas de água doce}

Segundo REBOUÇAS (2006, p. 7), embora mais de $3 / 4$ da superfície da Terra seja coberta por água, apenas $2,5 \%$ do volume total da água do planeta é doce. Deste volume, cerca de $68,9 \%$ da água doce encontra-se congelada, $29,9 \%$ está sob o solo e $0.9 \%$ sob a forma de umidade do solo. Rios e lagos representam apenas $0,3 \%$ da água doce do planeta. Esse pequeníssimo percentual torna fácil acatar sem maiores questionamentos o "mito" de que " $40 \%$ da população mundial sofre com escassez aguda de água" (dado mal interpretado de um estudo do Banco Mundial de 1995$)^{5}$ ou a profecia de que "se as guerras deste século se deram em torno do petróleo, as do próximo século serão lutas pela água", proferida pelo vice-presidente do BIRD (Banco Interamericano de Desenvolvimento), Ismail Serageldin, em 1995.

\footnotetext{
${ }^{4} \mathrm{~A}$ Infraestrutura Verde pode ser entendida com uma "rede de áreas naturais e áreas abertas (open spaces) fundamentais para o funcionamento ecológico do território, contribuindo para a preservação dos ecossistemas naturais, da vida selvagem, para a qualidade do ar e da água e para a qualidade de vida dos cidadãos." (FERREIRA; MACHADO, 2010, p. 69).

${ }^{5}$ Tal problema, na verdade, acometeria $4 \%$ da população mundial. Para mais detalhes ver Lomborg (2002, p. $25,186,187)$.
} 
No entanto, tal como acontece com a iminente (e jamais concretizada) falta mundial de alimentos anunciada há 200 anos por Thomas Malthus, confunde-se distribuição com escassez. A distribuição de água doce, de fato, parece ter aumentado: Rebouças avalia que no ano 2000 , cada habitante da Terra teria disponível de seis a setes vezes a quantidade mínima estimada como razoável pela ONU (Idem, p. 14)6.

Ainda assim, é preciso cuidado. Para a ONU, se não melhorarmos o manuseio das águas a proporção de pessoas em países com tensão hídrica aumentará de $3,7 \%$, em 2000, para 8,6\%, em 2025, e 17,8\%, em 2050.

A boa notícia é que ao contrário de muitos problemas ambientais que parecem insolúveis, a reversão da tendência acima pode ser bastante simples, com medidas de combate ao desperdício.

Os sistemas de irrigação da agricultura, de longe a maior consumidora de água doce do planeta, apresentam de 60 a $80 \%$ de perda. Enquanto no Brasil esse número é de $70 \%$, países tão díspares como Índia, Israel, EUA ou Espanha têm reduzido essas perdas a baixíssimos níveis.

Também podemos racionalizar o consumo se nos atentarmos ao fato de que algo como $90 \%$ das atividades que utilizam água potável poderia ser feita com água de reuso ou com água da chuva. Portanto pode-se obter considerável economia de água com medidas simples e tecnologia já desenvolvida.

\section{O abastecimento de água}

O Brasil é um país privilegiado no que diz respeito à quantidade de água potável que possui à sua disposição. Ainda que ocupe $5,7 \%$ das terras do planeta, tem em seu território nada menos do que $12 \%$ de toda a água potável do mundo (VAN KAICK, 2002, p. 35). E $53 \%$ da produção de água doce do continente sul-americano (REBOUÇAS, 2006, p. 27).

\footnotetext{
${ }^{6}$ Tentou-se confrontar esses dados com o conceito de pegada hídrica, desenvolvido pela WWF, mas o documento aqui referenciado não apresenta dados concretos sobre a pegada hídrica de São Paulo. No entanto, o estudo confirma a dificuldade de se trabalhar com a questão da disponibilidade de água doce: "A Pegada Hídrica acompanha somente a demanda humana por água doce e não a demanda de ecossistemas como um todo. Depende de dados locais frequentemente indisponíveis ou de difícil coleta. Sofre de possíveis erros de truncamento. Não existem estudos sobre incertezas de dados, embora as incertezas sejam significantes". (WWF, 2012, p. 43,44)
} 
No entanto, se há motivos para alegria, há também motivos para lamentação: no Brasil, perde-se algo entre 37 e $42 \%$ da água potável no processo de distribuição, segundo dado divulgado em setembro de 2011 pelo Sistema Nacional de Informações sobre o Saneamento (SNIS), do Ministério das Cidades. O Japão, referência mundial no assunto, atingiu a marca de pífios $3 \%$.

Segundo o levantamento "Indicadores do Desenvolvimento Sustentável - Brasil 2012", do IBGE,

Em todo o País tem crescido continuamente, ao longo do período analisado, o percentual da população com abastecimento de água considerado adequado, tendo alcançado 93,1\% na zona urbana em 2009. Os percentuais são menores na zona rural $(32,8 \%)$, que é mais atendida por outras formas de abastecimento de água, como poço ou nascente e outros tipos. Os percentuais de população abastecida por rede geral de água nas áreas urbanas são mais elevados na Região Sudeste $(97,1 \%)$ e na Região Sul $(95,3 \%)$ do que nas Regiões Nordeste (92,0\%), Centro-Oeste (91,6\%) e Norte (93,1\%). (p. 108,109)

O estudo aponta que o estado de São Paulo destaca-se com 99,3\% da população atendida por rede de abastecimento de água, o que se reverte em melhoria das condições de saúde e higiene, e, portanto, melhor qualidade de vida, um dos principais indicadores para se aferir o desenvolvimento sustentável.

\section{O esgotamento sanitário}

O esgotamento sanitário é um serviço de importância crucial para a qualidade de vida das pessoas já que controla e reduz doenças, ajudando a minimizar o impacto dos assentamentos humanos sobre os ecossistemas. Em nítido contraste com os elevados níveis de abastecimento de água do país, o estudo do IBGE apresenta dados bem mais modestos relativos ao esgotamento sanitário:

aproximadamente $80 \%$ dos moradores em áreas urbanas e $25 \%$ daqueles em áreas rurais eram providos de rede geral de esgotamento sanitário ou de fossa séptica. Enquanto o percentual de domicílios urbanos atendidos por rede coletora tem aumentado continuamente, o percentual dos atendidos por fossa séptica tem se mantido estável, com tendência de queda a partir de 2008. (...) Nas áreas urbanas, as Unidades da Federação com os maiores percentuais de atendimento por rede coletora nos domicílios, em 2009, eram: São Paulo 
(91,1\%), Distrito Federal $(89,4 \%)$ e Minas Gerais $(89,1 \%)$. Os menores percentuais foram verificados no Amapá (1,1\%), no Pará (2,7\%), e em Rondônia (5,2\%). Nas áreas rurais, os maiores percentuais ocorreram em São Paulo (44,3\%), no Distrito Federal (22,6\%) e no Rio de Janeiro (17,9\%), e os menores no Rio Grande do Sul, no Tocantins e na Paraíba (0,5\%, cada). (Idem, p. 114, 115)

Pode-se observar, portanto, que o nosso país possui um grande degrau entre os serviços de abastecimento e de tratamento de esgoto.

\section{O tratamento de esgoto}

Ainda que o abastecimento de água e o esgotamento sanitário sejam fundamentais para a qualidade de vida, e consequentemente para a medição do desenvolvimento sustentável, o ponto fulcral do ciclo da água nos assentamentos humanos, principalmente no que diz respeito à preservação da qualidade das águas doces e da não contaminação dos ecossistemas é o tratamento do esgoto coletado antes de sua disposição nos corpos d'águas e sumidouros.

A ausência de tratamento compromete todas as atividades que dependem dos corpos d'água, desde a pesca até a recreação, passando pela irrigação de áreas cultivadas para a produção de alimentos e o fornecimento de água para animais na pecuária. Em determinados níveis, a presença de esgoto nos corpos d'água contribui ainda para a proliferação de doenças. Neste sentido, os dados apresentados pelo levantamento do IBGE, embora retratem uma evolução na prestação desse serviço, são bastante preocupantes:

No ano de 1995, no conjunto dos municípios commais de 100000 habitantes, apenas $8,7 \%$ do total do esgoto coletado foi tratado. No ano de 2005, esta razão passou a ser de 61,6\%. Nos anos de 2006 a 2008, a partir da mudança na metodologia da coleta dos dados, os percentuais foram, respectivamente, $60,7 \%, 62,9 \%$ e $66,2 \%$. Em relação às Grandes Regiões, no ano de 1995, a Região Sudeste apresentava somente $1,5 \%$ do esgoto coletado tratado, abaixo do percentual no Brasil (8,7\%). Por outro lado, as Regiões Nordeste e Centro-Oeste possuíam os maiores percentuais tratados (44,8\% e 33,4\%, respectivamente), superiores à média do País como um todo. Já em 2005, o percentual no Brasil é de $61,6 \%$ e as Regiões Norte e Sudeste apresentam percentuais inferiores (50,7\% e 51,8\%, respectivamente). As Regiões Nordeste, Centro-Oeste e Sul apresentam os maiores percentuais (90,1\%, 79,6\% e 77,8\%, respectivamente). No ano de 2008, as Regiões CentroOeste $(88,9 \%)$, Nordeste $(86,4 \%)$ e Sul $(78,8 \%)$ apresentam os maiores percentuais de tratamento do esgoto coletado. (Idem, p. 126) 
O estudo Panorama da Qualidade das Águas Superficiais - 2012, da ANA (Agência Nacional de Águas) apresenta dados em que fica claro como o quadro descrito se materializa em um acentuado grau de degradação da qualidade das águas urbanas do país quando comparado com o panorama geral das águas superficiais do Brasil (Figura 2). O estudo informa que enquanto apenas $7 \%$ dos 1.988 pontos monitorados apresentaram índice de qualidade das águas péssimo ou ruim, o número salta para $47 \%$ quando considerados somente os corpos d'água em áreas urbanas.

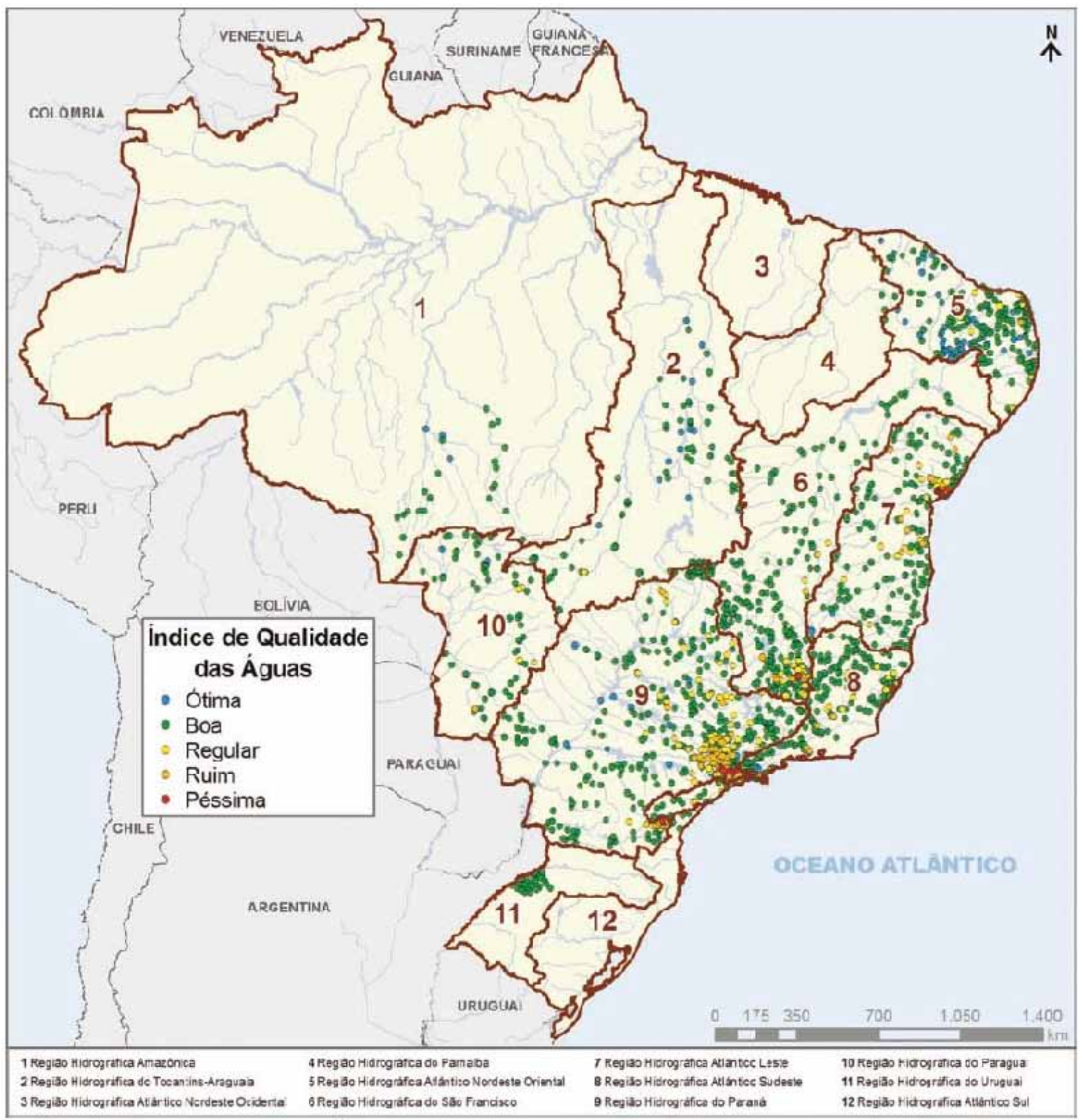

Figura 2 - Índice de Qualidade das Águas - Valor Médio em 2010. Fonte: Agência Nacional de Águas, 2012. 
Segundo o estudo, esse quadro de degradação das águas urbanas pode ser explicado como reflexo de uma combinação entre alta taxa de urbanização e baixos níveis de coleta e tratamento de esgotos domésticos.

\section{REPENSANDO O CICLO DA ÁGUA NOS ASSENTAMENTOS HUMANOS}

A dificuldade de prover saneamento básico para todos talvez se explique em parte pela inviabilidade econômica de se instalar Estações de Tratamento de Esgoto convencionais em pequenas cidades e comunidades rurais. Conforme explica ZANELLA,

esses sistemas mecanizados são a melhor opção para grandes metrópoles onde o espaço livre para a construção de ETEs é cada vez mais raro, mas em municípios menores ou comunidades isoladas a complexidade e a dependência geradas por esse tipo de estação torna-se uma barreira, se não para sua implantação, ao menos para a sua operação que envolve elevados custos de manutenção e exigência de operação especializada, nem sempre disponível. (2008, p. 22)

Por outro lado, a falta do saneamento básico universal também pode ser explicada como fruto de um embate entre duas visões de mundo bastante diferentes sobre o mesmo assunto: a do conservadorismo tecnicista da engenharia civil, que calcada no sanitarismo ${ }^{7}$ do século $\mathrm{XX}$, vê com desconfiança tudo o que é relacionado à água, e a do romantismo ecológico daqueles que propõe sistemas de tratamento de água baseados no uso de vegetação, geralmente orientados por uma romântica visão de natureza como a morada de todas as virtudes em declarada oposição ao que é tocado pela mão do homem - notadamente a ciência, a economia e a cidade.

Quem perde com tal embate, evidentemente são as pessoas e os ecossistemas, que permanecem sem tratamento de esgoto por uma suposta inexistência de alternativas viáveis. (E de vontade política, pode-se acrescentar).

\footnotetext{
${ }^{7}$ Franco (1997, p. 78) explica que "o movimento higienista desde suas origens (fins do séc. XVIII), valeu-se da 'teoria dos meios'. Esta insistia em que os males eram advindos da estagnação de todo o tipo - água, lixo e homens. Dessa forma a circulação transformou-se na palavra de ordem da engenharia sanitária". Isso permite entender porque, aparentemente, todo o sistema de drenagem de São Paulo parece ter sido pensado de modo a fazer a água 'sumir' o mais rapidamente possível de nossa vista.
} 
É neste contexto delicado e complexo que se propõe aqui a identificação, a compreensão e a análise de sistemas de tratamentos de águas que mimetizam ecossistemas naturais alagáveis.

\section{AS LIÇÕES DO PÂNTANO OU PORQUE OS SISTEMAS DE TRATAMENTO DE ÁGUA COM USO DE VEGETAÇÃO MIMETIZAM ECOSSISTEMAS ÚMIDOS E NÃO OUTROS ECOSSISTEMAS}

De oceanos a desertos, dos Alpes suíços à floresta amazônica, todos os ecossistemas obedecem aos princípios da termodinâmica. Sua primeira lei determina que um tipo de energia pode ser transformado em outro. As plantas, por meio da fotossíntese, fazem isso durante o dia, transformando a energia solar em energia química. E é este "pequeno milagre", que compartilhado via cadeia alimentar, possibilita a vida em nosso planeta e consegue amenizar os efeitos da implacável segunda lei da termodinâmica: a de que a cada transformação de energia, parte da energia inicial se dispersa em formas irrecuperáveis.

Embora geralmente sejam expressas em termos de energia, as leis da entropia também se aplicam à matéria. No entanto, é importante observar que, enquanto a energia entra e sai dos ecossistemas o tempo todo (chegando como luz e saindo como calor, por exemplo), a matéria tende a ser retida dentro do ecossistema, conservando-se em níveis constantes através dos processos de ciclagem de nutrientes e de decomposição da matéria orgânica.

As plantas também são capazes de realizar um segundo "milagre", este bem menos reverenciado: o de transformar matéria orgânica em inorgânica. E vice-versa.

Embora todos os ecossistemas sejam capazes de realizar os processos descritos acima, ODUM (1988) explica que os "ecossistemas de terras alagadas" são mais eficientes no que diz respeito à capacidade de ciclar nutrientes e matéria orgânica porque o fluxo de água "age como subsídio energético" (p. 169).

RICKLEFS descreve os alagados como

áreas de terra consistindo em solo saturado com água e que sustentam uma vegetação especificamente adaptada a estas condições. Os alagados incluem pântanos, brejos e lamaçal quando derivam de água doce, e brejos salgados e manguezais quando associados a ambientes marinhos. (2011, p. 95) 
ODUM explica que os alagados podem estar saturados de água continuamente ou apenas durante parte do ano e que também são caracterizados por serem sistemas muito abertos. O autor explica que a produtividade dos alagados é determinada pela flutuação do nível da água, e ilustra essa capacidade com um dado impressionante: "embora os alagados ocupem apenas cerca de $2 \%$ da área do mundo, estima-se que contêm de 10 a $14 \%$ do carbono. (...) Alguns solos de áreas alagadas podem conter até $20 \%$ de carbono por peso" (1988, p. 370).

Fica fácil perceber, portanto, como é problemática a supressão de tais ecossistemas pelas atividades humanas. Além de comprometer um importante serviço ambiental já que "os sedimentos dos alagados imobilizam substâncias poluentes potencialmente tóxicas dissolvidas na água" (RICKLEFS, 2011, p. 95), adicionalmente, a conversão de um mangue em um resort turístico, por exemplo, ou a drenagem de um brejo para a o desenvolvimento de atividades agrícolas, liberam grandes quantidades de CO2 na atmosfera, contribuindo com a amplificação das mudanças climáticas.

O relatório Ecossistemas e bem-estar humano: estrutura para uma avaliação, das Nações Unidas, ressalta os benefícios obtidos com a regulação dos processos dos ecossistemas, entre eles, a purificação da água e o tratamento de refugos: "Os ecossistemas podem ser uma fonte de impurezas na água doce, mas também podem ajudar a filtrar e decompor refugos orgânicos introduzidos em águas interiores e ecossistemas litorâneos e marinhos". (CONSELHO DE AVALIAÇÃO ECOSSISTÊMICA DO MILÊNIO, 2005, p. 107).

A recente proposta do "novo" Código Florestal de se retirar a proteção aos mangues e aos apicuns, deixa claro que as lições quanto à importância de se preservar os ecossistemas alagados ainda não foram plenamente compreendidas. Paradoxalmente, o entendimento acerca do funcionamento desses ecossistemas tem evoluído a passos largos, consolidando-se na arquitetura paisagística, nas engenharias civil e ambiental e na permacultura, por meio de tipologias construtivas que mimetizam zonas úmidas e que são versáteis o suficiente para serem aplicadas tanto na escala do lote residencial quanto na escala do planejamento urbano.

\section{A VEGETAÇÃO COMO TECNOLOGIA PARA A PURIFICAÇÃO DA ÁGUA}

"Tratamento de água por zona de raízes", "wetlands construídos", "círculo de bananeiras", "bacia de evapotranspiração", "ilhas flutuantes", "filtros plantados", "jardins filtrantes" e "leitos de macrófitas" são os nomes de alguns desses métodos de tratamento e polimento da água por meio do uso de vegetação. 


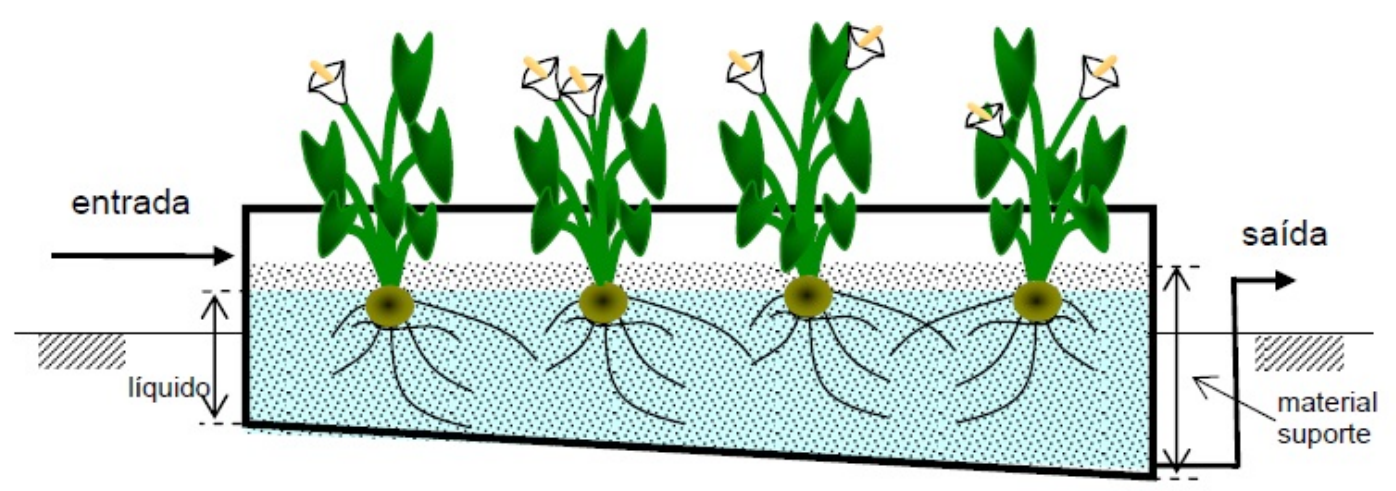

Figura 3 - Representação esquemática em corte de um wetland construído. Fonte: Zanella, 2008.

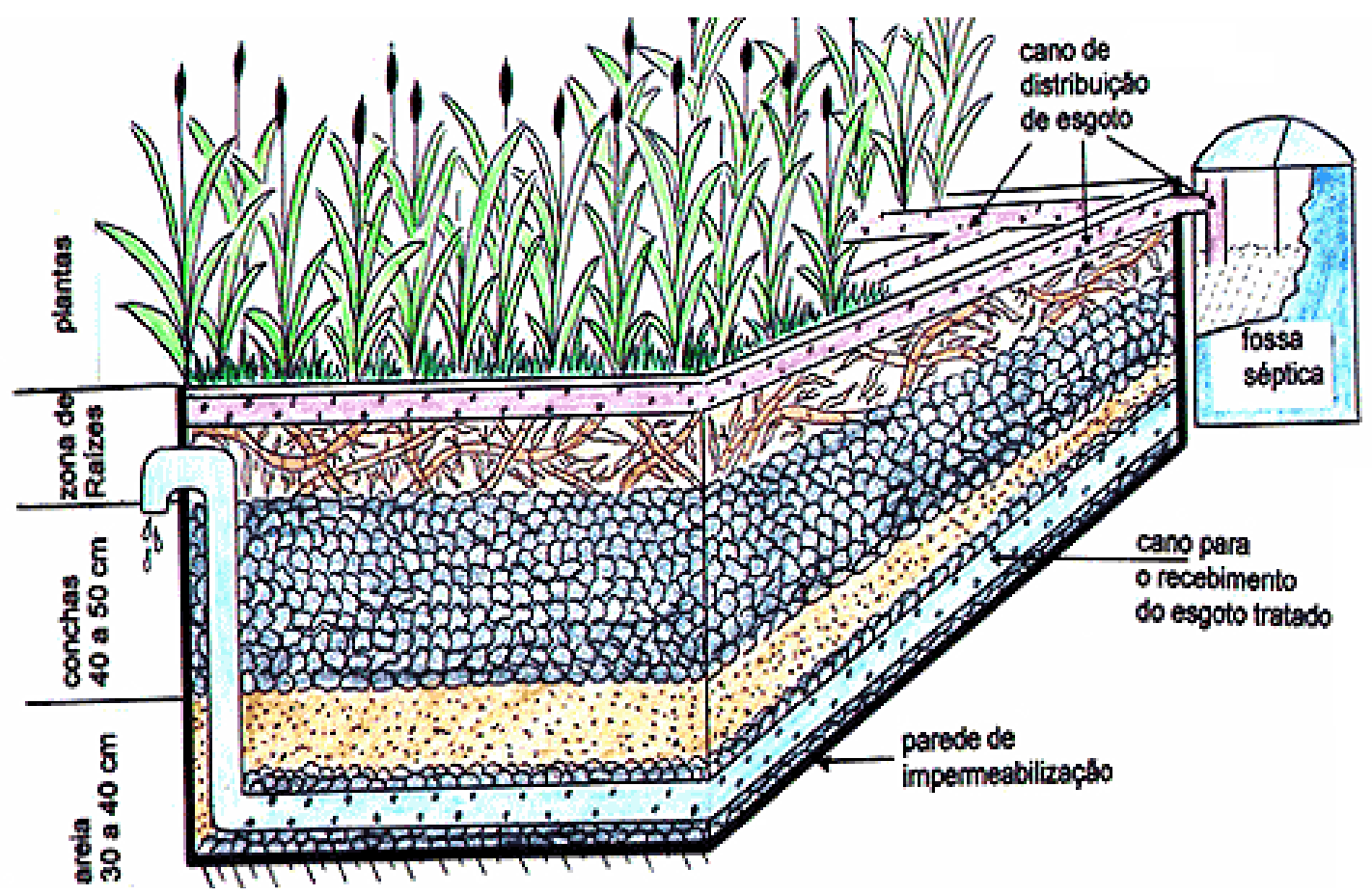

Figura 4 - Esquema de Zona de Raízes. Fonte: Van Kaick, 2002.

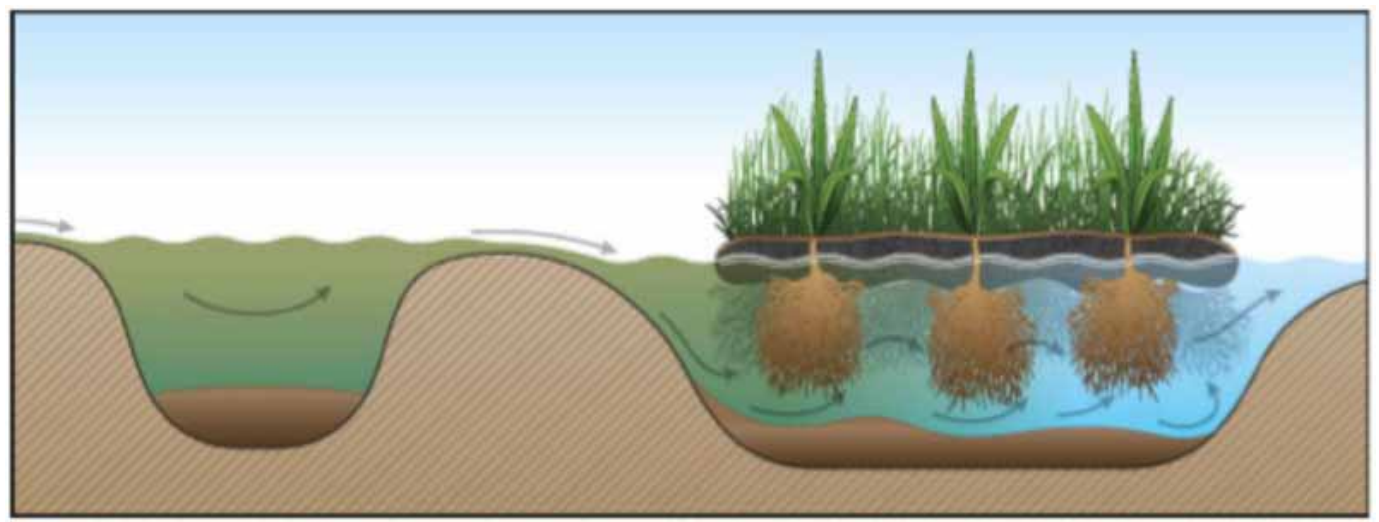

Figura 5 - Corte de llha Flutuante. A bacia de sedimentação à esquerda é opcional. Fonte: www.sahajowater.com 
Cada uma dessas tipologias construtivas possuem particularidades (ver Figuras 3, 4 e 5). Em comum, valem-se de propriedades, ciclos e mecanismos naturais para efetuar a limpeza da água que estão, resumidamente, elencados a seguir. Van Kaick (2002), Izembart; Le Boudec (2003), France (2003), Zanella (2008) e Horn (2011) e explicam que:

- As raízes de muitas plantas abrigam colônias de microrganismos que decompõem a matéria orgânica (biofilme). Dessa decomposição surgem nutrientes que são utilizados pelas plantas.

- Os vegetais possuem estruturas chamadas aerênquimas, pequenos canais capazes de transportar oxigênio e nitrogênio das folhas para as raízes. Esse fluxo é importante porque as bactérias precisam desses elementos químicos para realizar a decomposição de matéria orgânica.

- O fluxo de oxigênio da folha para a raiz tem a capacidade de oxigenar ambientes aquáticos, possibilitando os processos de decomposição aeróbicos mesmo em efluentes com grande carga de matéria orgânica.

- A introdução de oxigênio no solo é necessária para que ocorram os processos de oxidação de metais pesados e gases a base de enxofre.

- O oxigênio causa a morte de germes e bactérias causadoras de doenças.

- As raízes têm a capacidade de filtrar os gases gerados pelos processos aeróbicos e anaeróbicos de decomposição de matéria orgânica, evitando a exalação de odores.

- As raízes retém material particulado.

- A evapotranspiração das plantas providencia o retorno da água à atmosfera em forma de vapor exalado pelas folhas, o que pode levar à concentração do efluente.

- Raízes de plantas com os juncos da família Phragmites produzem substâncias que atuam na eliminação de coliformes fecais e outras bactérias patogênicas podendo-se atingir índices de 99,99\% de eficiência.

Entre as tipologias construídas que imitam processos naturais presentes em ecossistemas de áreas úmidas, as chamadas llhas Flutuantes, vêm ganhando enorme destaque. Segundo Charman (2003), a reunião de três sistemas aquáticos diferentes - pântano, rio e lago - está possibilitando que peixes, bactérias e o sistema radicular de vegetação aquática trabalhem em conjunto para limpar águas extremamente poluídas. 
O caso mais emblemático é, provavelmente, o Baima Canal, na cidade chinesa de Fuzhou. Em 2002, o canal de 600 metros de extensão recebia 2840m3 de esgoto bruto por dia. Em apenas um ano, com a instalação das ilhas flutuantes, o canal ficou irreconhecível: de um local extremamente degradado, converteu-se em uma paisagem desfrutada pela população, abrigando 10 mil carpas e 100 mil plantas (Figura 5). E o esgotamento de 12 mil pessoas continua sendo feito no local, com tratamento realizado a um custo estimado U\$10 dólares/pessoa/ano, ao invés dos 80 dólares do tratamento convencional.
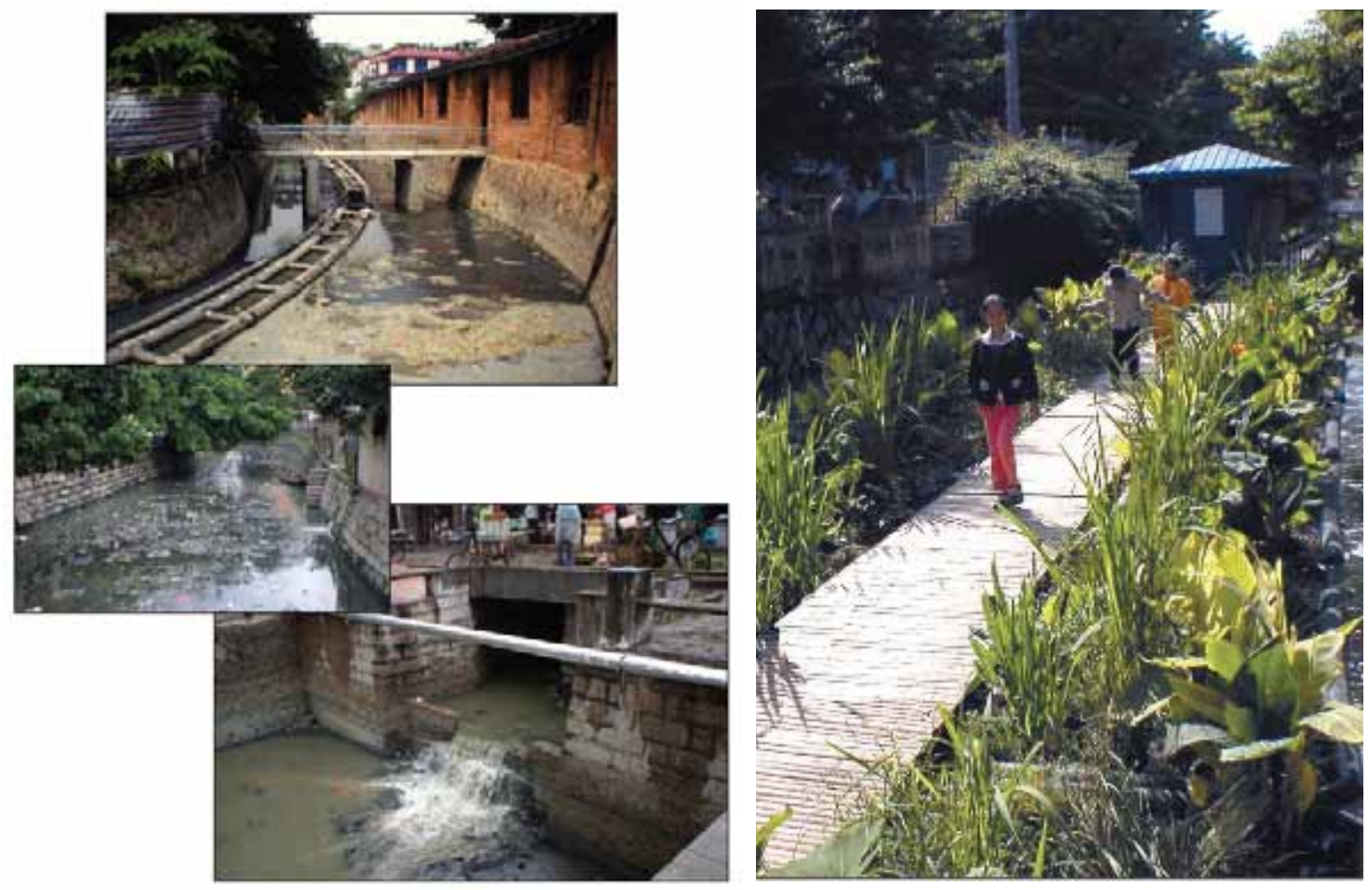

Figura 6 - Baima Canal. Antes e depois. Fonte: John Todd Ecological Design.

A vegetação a ser usada no tratamento de água por vegetação devem ter algumas características:

- tolerar áreas permanentemente saturadas ou submersas;

- ter aerênquimas bem desenvolvidas;

- possuir raízes em forma de cabeleira;

- serem, preferencialmente, nativas da região.

O uso de exóticas deve ser criterioso, já que muitas delas podem se tornar uma praga. 


\section{OUTRAS TECNOLOGIAS DA NATUREZA PARA O TRATAMENTO DE ÁGUA}

Além do uso de plantas, outros elementos naturais, geralmente associados a elas, ajudam na purificação da água. O solo dá suporte para a vegetação e funciona como "uma camada filtrante que possibilita ações de sorção e a atividade microbiológica que mineraliza a matéria orgânica ainda contida no efluente, disponibilizando os minerais e nutrientes para a vegetação" (ZANELLA, 2008, p. 24).

A variação no nível da água contribui com a ciclagem de nutrientes. Por isso, as tipologias valem-se, em maior ou em menor grau, de diferentes arranjos quanto ao nível da água em relação ao leito, o grau de submersão das plantas e a existência de zonas de transição entre as duas situações anteriores, conforme ilustrado na figura 7 .

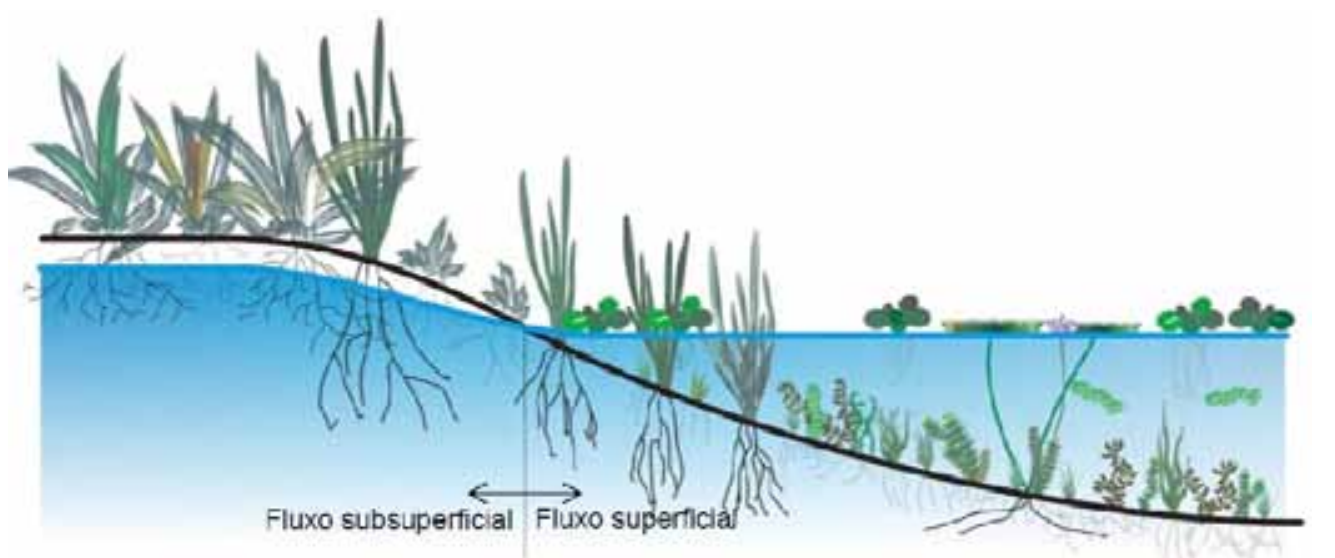

Figura 7 Representação esquemática de um wetland natural. Fonte: Zanella, 2008.

Uma determinada combinação entre os componentes solo, planta e água pode ser mais eficiente no que diz respeito à decomposição de matéria orgânica, enquanto outra pode priorizar a erradicação de patógenos. Para esta finalidade, exige-se menor quantidade de vegetação a fim de possibilitar maior exposição à radiação solar, que tem a capacidade de controlar a população de organismos patogênicos.

A profundidade da água e o seu fluxo também determinam outros serviços dos sistemas naturais de tratamento de água. Em lâminas de água de até $0,50 \mathrm{~m}$ de profundidade há a tendência a predominar os processos aeróbicos de decomposição de matéria orgânica. Para profundidades maiores, predominarão os processos anaeróbicos e anóxicos de decomposição de matéria orgânica.

O sentido do fluxo (de baixo para cima ou vice-versa) influencia na capacidade de sedimentação dos sistemas construídos, bem como na aeração da água que está sendo tratada. 
Percebe-se que a tendência hoje é de que os sistemas de tratamento que utilizam vegetação tenham duas ou mais áreas construídas com diferentes tipologias de escoamentos entre si, isto é, diferentes combinações entre meio suporte, planta, nível da lâmina de água e sentido de fluxo de efluentes ${ }^{8}$.

\section{EXPERIÊNCIAS BRASILEIRAS}

Embora sejam relativamente comuns na Europa e nos Estados Unidos, ainda são raros no Brasil os sistemas de tratamento de água com uso de vegetação fora de ambientes de pesquisa.

Na Praça Victor Civita, em São Paulo, a água da chuva e o esgoto do prédio do Museu são transportados por canaletas para o sistema de alagados, passando por uma camada filtrante de cascalho e plantas aquáticas. (Figuras 8, 9,10 e 11)
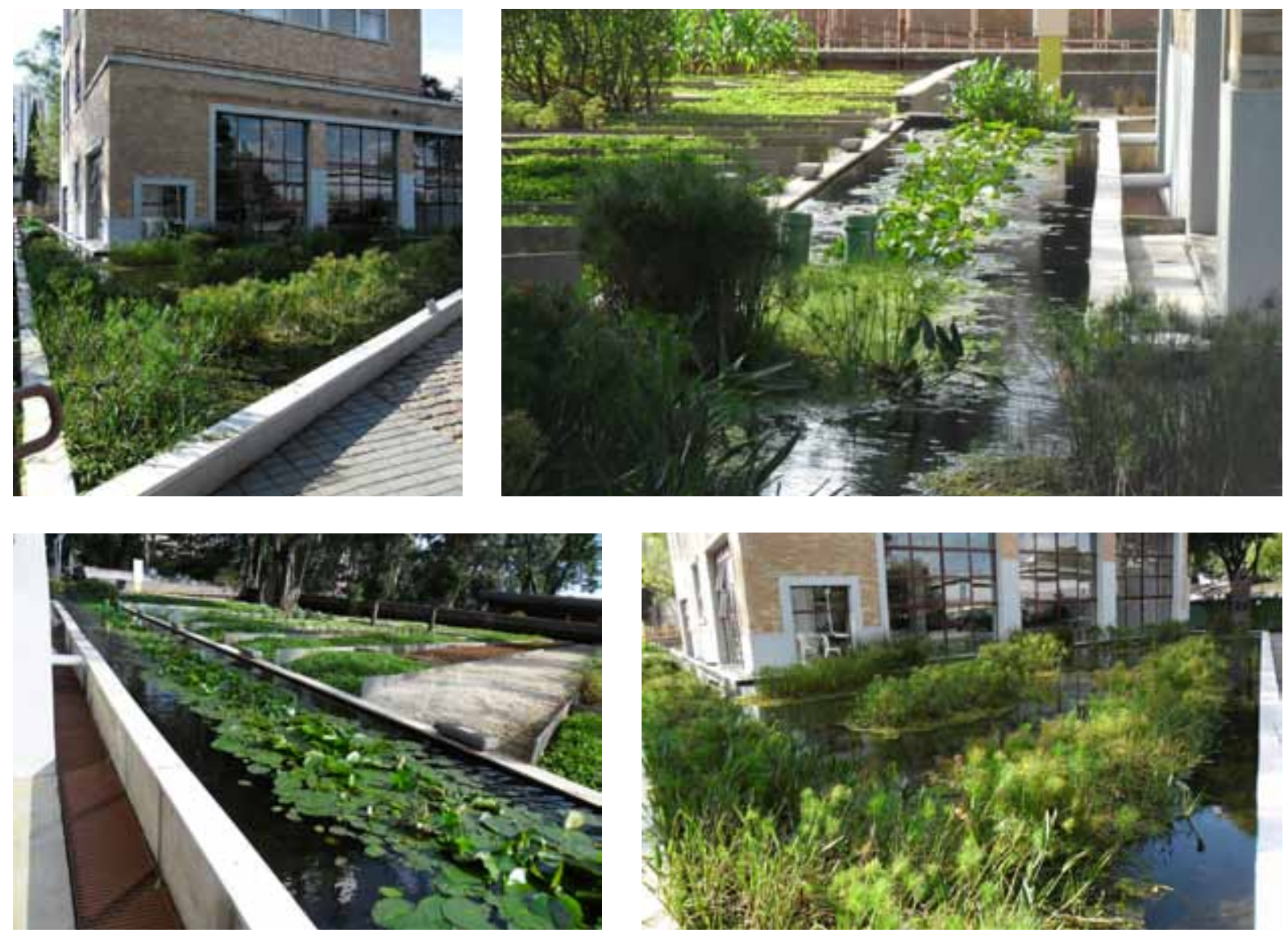

Figuras 8, 9, 10 e 11 - Wetland Construído da Praça Victor Civita, em São Paulo.

\footnotetext{
${ }^{8}$ Os wetlands construídos costumam ser classificados em sistemas de escoamento superficial ou subsuperficial e subdivididos quanto ao fluxo de efluentes, que pode ser horizontal ou vertical. Neste, o fluxo pode ser ascendente ou descendente. A vegetação pode ser submersa, flutuante, emergente ou fixa de folhas flutuantes.
} 
Esses sistemas não convencionais de tratamento de água também apresentam a vantagem de não terem rejeição por parte da população, ao contrário do que se verifica com as estações de tratamento de esgoto convencionais.

De fato, pode-se verificar que quando essas tipologias construtivas recebem tratamento paisagístico adequado, a função de tratamento de efluentes muitas vezes passa despercebida pela população do entorno e pelos usuários desses espaços. Esse fenômeno foi observado em visita técnica ao Parque da Juventude (Luis Latorre) localizado em Itatiba, município que faz parte da região metropolitana de Campinas.

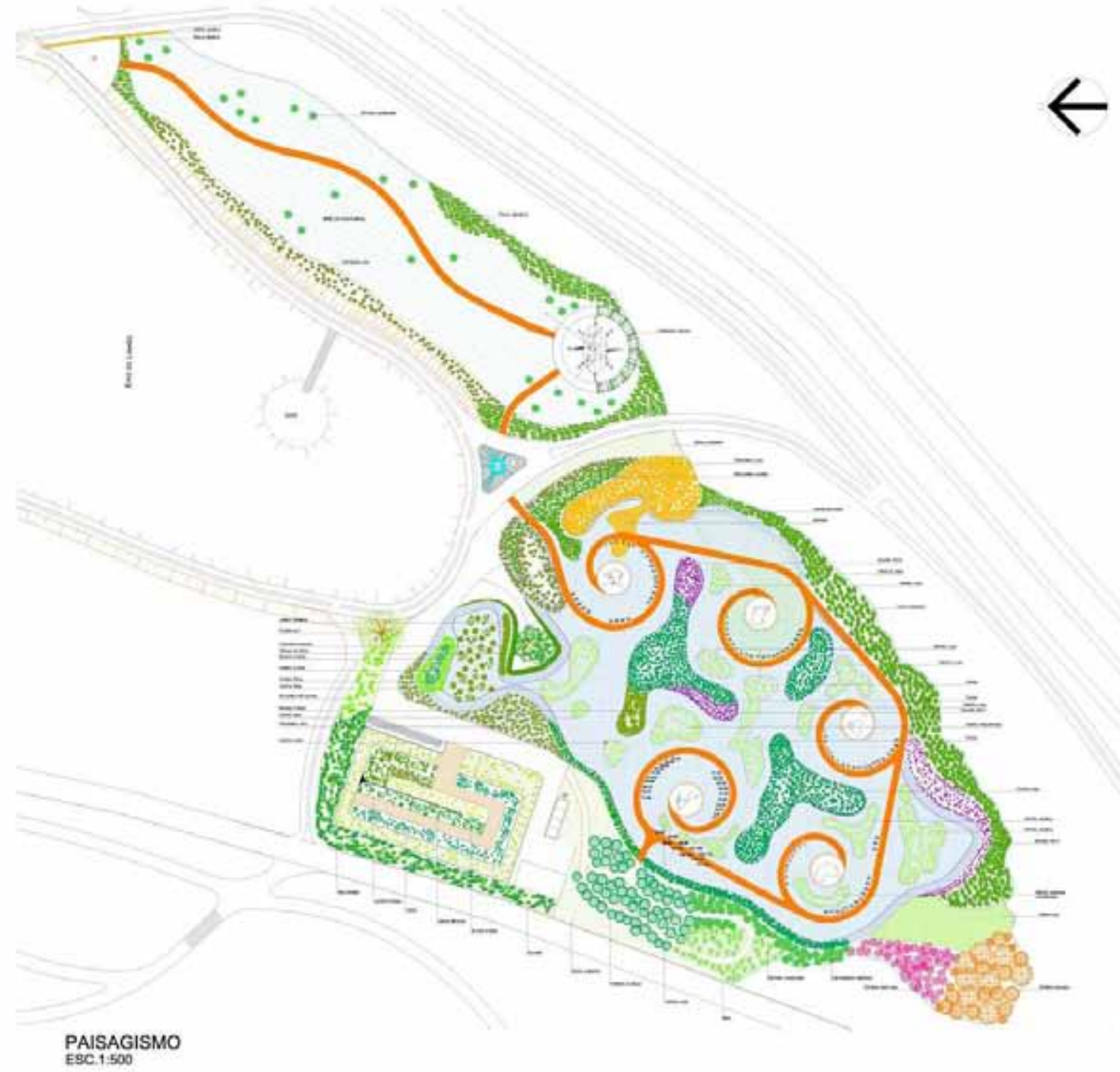

Figura 12 - Planta de Paisagismo da gleba Águas do Mundo, no Parque da Juventude (Pq. Municipal Luis Latorre), em Itatiba, SP. Fonte: Eng. André Bailone, da Itubanaiá (empresa responsável pelo projeto). 
Uma de suas áreas, a gleba Águas do Mundo (Figura 12), faz o tratamento da água poluída que chega de uma encosta vizinha ${ }^{9}$, como pode ser visto nas figuras $13,14 \mathrm{e}$ 15. O sistema de wetlands recebeu um tratamento paisagístico (figuras 16 e 17) que compatibilizou o tratamento de águas com o lazer dos usuários do parque (figuras 18, 19 e 20), oferecendo ainda um estimulante ambiente para a educação ambiental (figura 21) e refúgio para biodiversidade (figuras 22, 23 e 24).
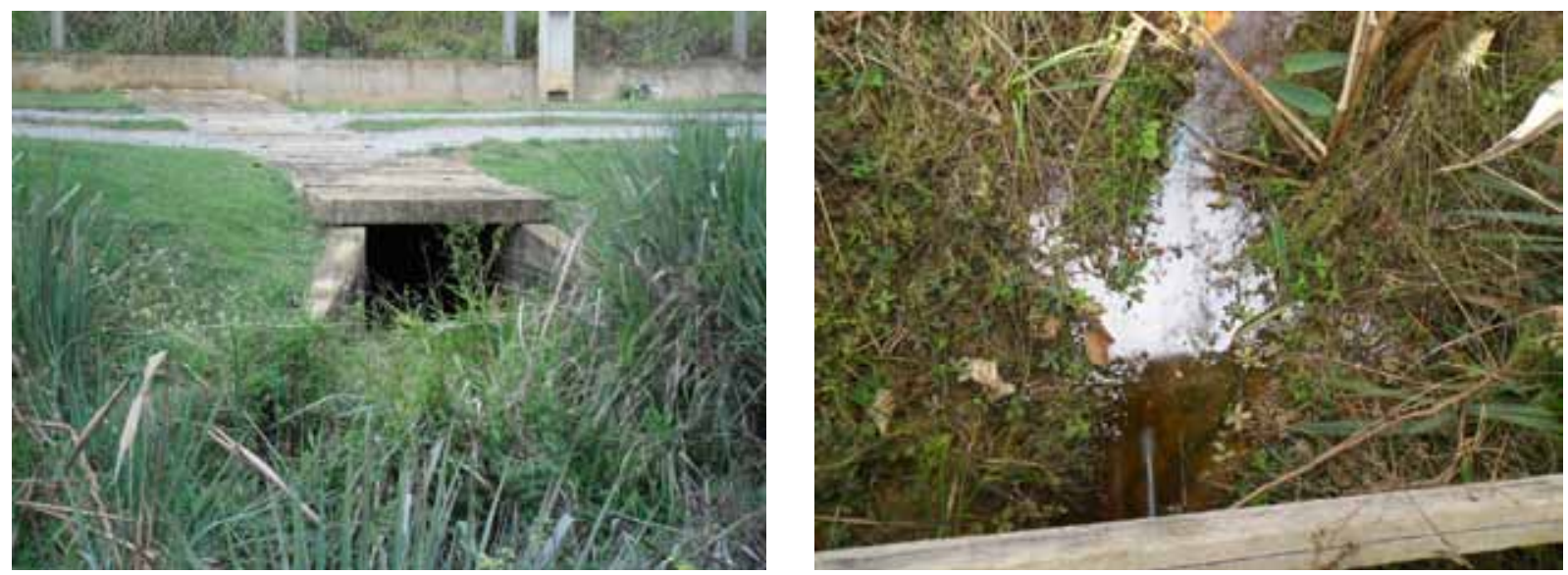

Figuras 13 e 14 - Qualidade da água ao entrar no Parque da Juventude (Luis Latorre).

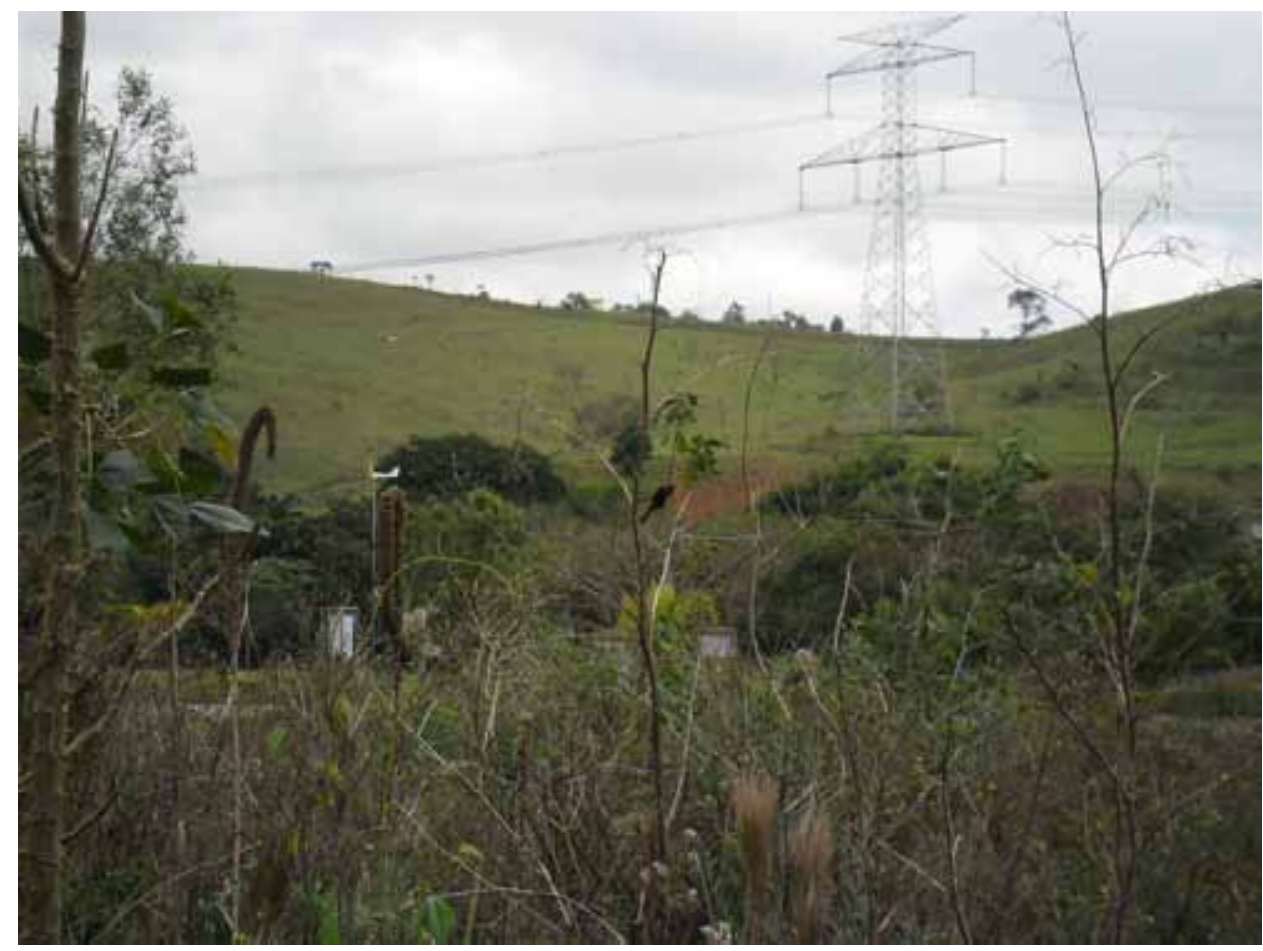

Figura 15 -

A encosta, fonte da água suja que é tratada no sistema.

\footnotetext{
${ }^{9} \mathrm{~A}$ proposta inicial era tratar a água do poluído reibeirão Jacaré, vizinho ao parque. No entanto a morosidade do licenciamento ambiental e pressões para a inauguração do parque em ano eleitoral forçaram a mudança do projeto.
} 

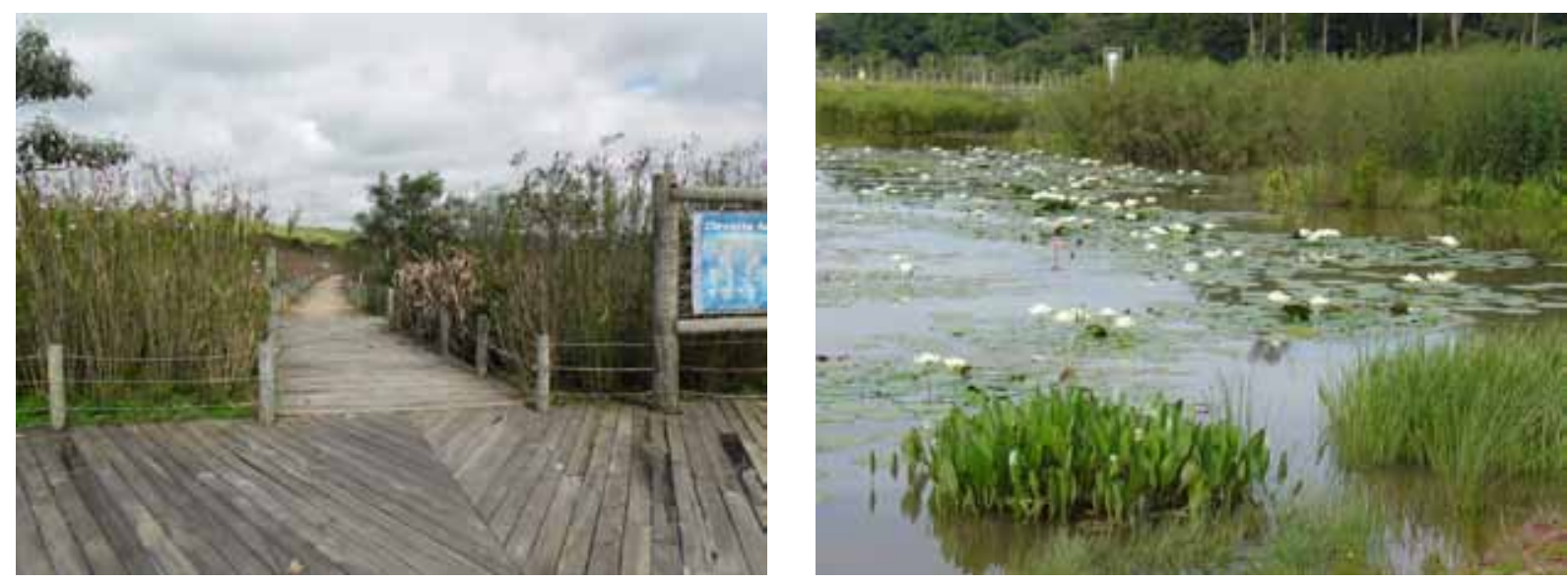

Figura 16 e 17 - Tratamento paisagístico do Parque. Fonte da figura 17: Eng. André Bailone, da Itubanaiá (empresa responsável pelo projeto).'
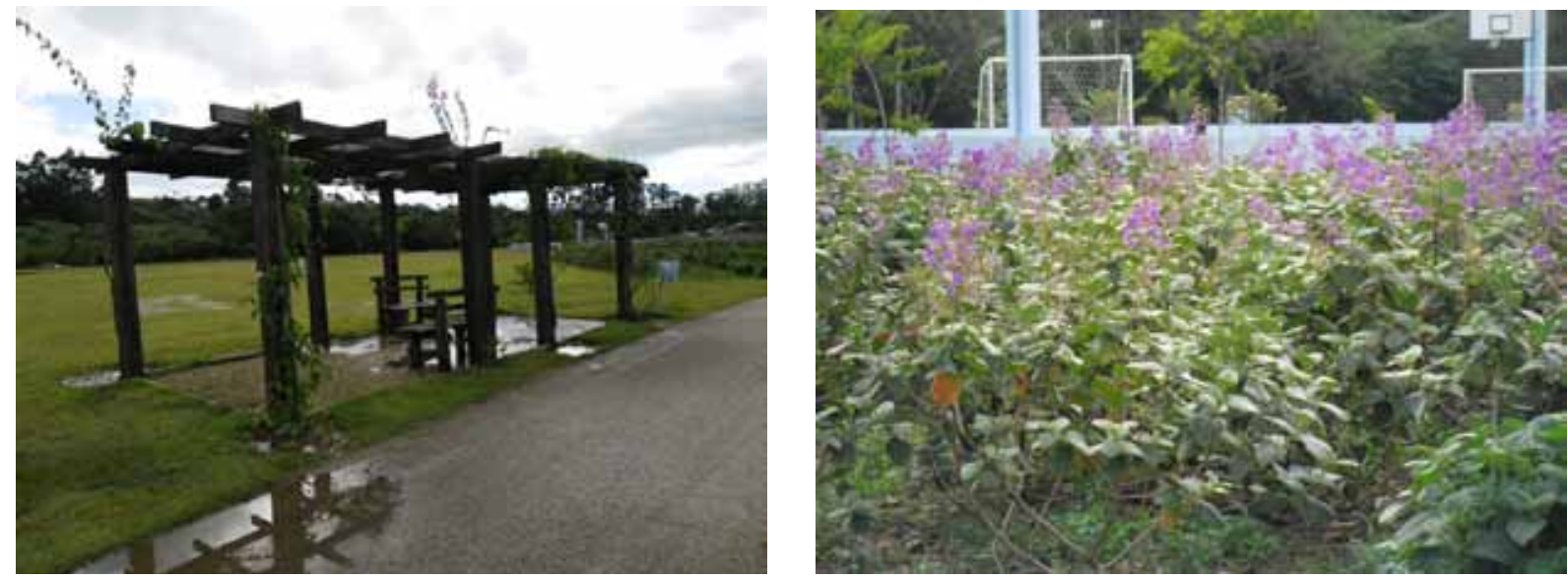

Figuras 18 e 19 - Alguns equipamentos de lazer e paisagens que não se espera encontrar em uma estação de tratamento.

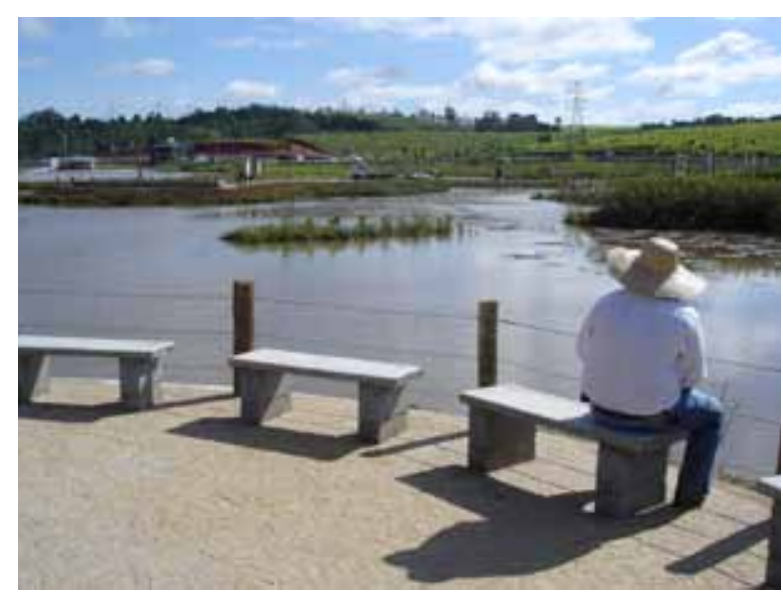

Figura 20 - A inusitada possibilidade de contemplar um sistema de tratamento de águas sujas. Fonte: Eng. André Bailone, da Itubanaiá (empresa responsável pelo projeto).

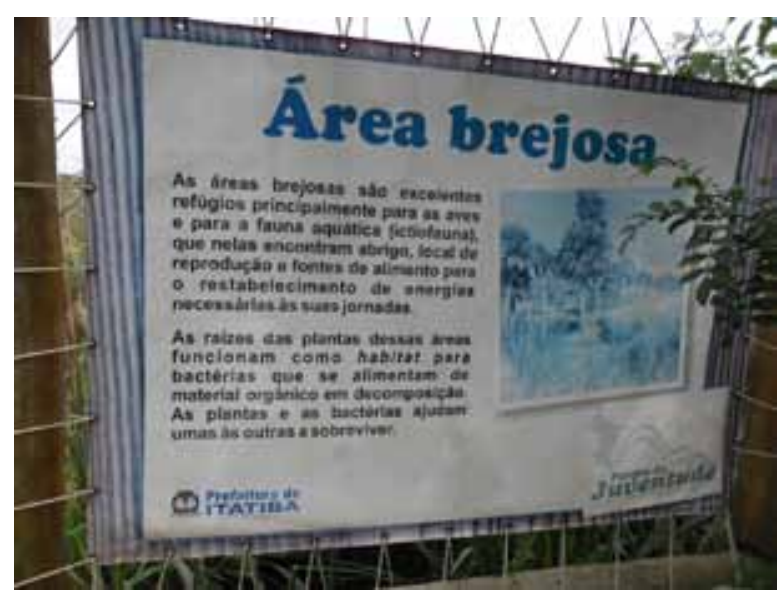

Figura 21 - Painel junto à passarela na área brejosa serve de apoio para a educação ambiental. 

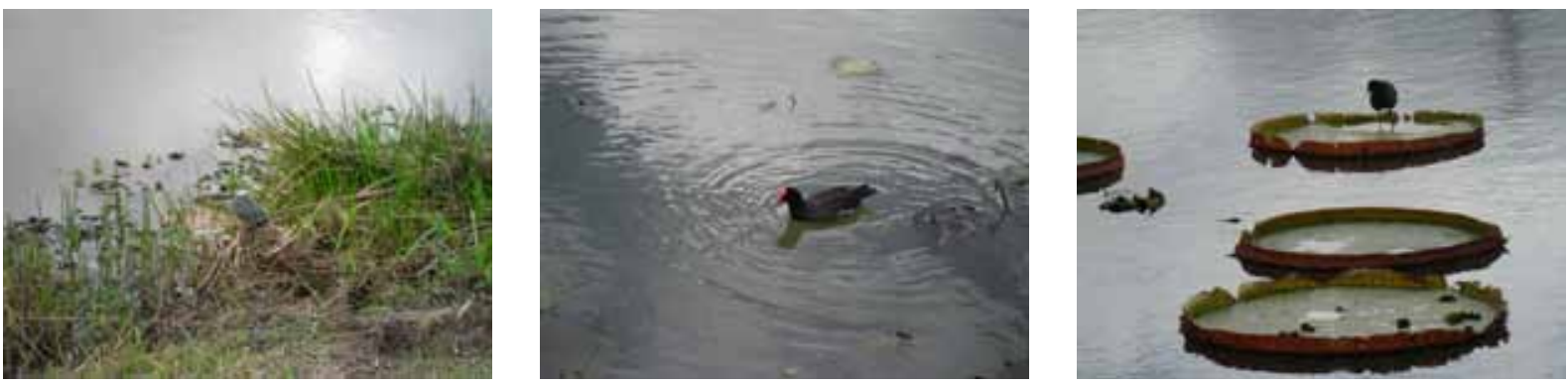

Figuras 22, 23 e 24 - Wetlands construídos são ambientes de refúgio da biodiversidade, como ocorre no Parque da Juventude (Luis Latorre).

Conversas informais com usuários do parque revelaram que nenhum deles sabia da função de tratamento de água desempenhada pelo parque. Nenhum dos entrevistados relatou já ter sentido odores desagradáveis no local. Questionados sobre a beleza do lugar, a avaliação foi positiva. Cerca de metade era frequentadora assídua, utilizando o parque para atividades de caminhada e cooper.

\section{CONSIDERAÇÕES FINAIS}

São bastante conhecidos os efeitos deletérios que o despejo de efluentes sanitários no meio ambiente pode causar, mas pouco conhecidas são as alternativas existentes às estações de tratamento convencionais.

A literatura consultada aponta para viabilidade técnica dos sistemas de tratamento e polimento de água baseados no uso da vegetação. De baixo custo e simples operação, esses sistemas inspirados pela natureza podem colaborar para que os cerca de $45 \%$ de municípios brasileiros que não são atendidos por redes coletoras de esgoto possam tratar os seus efluentes, inclusive de maneira descentralizada e na escala do lote.

Ainda que seja crescente a produção acadêmica sobre sistemas de tratamento de água com uso de vegetação, pouquíssimos são os estudos acerca de sua dimensão paisagística. Raras também são as pesquisas acerca de como tais espaços consentem outros usos.

Nossos estudos de caso, no entanto, evidenciam que tais sistemas são capazes de oferecer outros usos e serviços relacionados ao lazer, ao fomento da biodiversidade e à educação ambiental. No que tange ao planejamento urbano e regional, esses espaços podem ser vistos como zonas de amortecimento entre unidades de 
conservação (tais como parques nacionais, reservas biológicas e estações ecológicas) e áreas urbanas ou agrícolas. Em outras palavras, são peças-chave da infraestrutura verde - existente ou sonhada - de cidades e assentamentos de todos os tamanhos.

Apesar dos muitos estudos e sistemas construídos em todo o mundo, parece haver uma dimensão inexplorada, que é a desses espaços serem desenhados como unidades produtivas já que é possível utilizar espécies vegetais que produzem materiais com valor econômico, tais como flores de corte ('copo de leite' - Zantedeschia aethiopica e helicônias-Heliconia spp, por exemplo), fibras para confecção de cestos e artesanato (taboa - Typha spp e junco - Juncus spp), papel (papiro - Cyperus papyrus) e até mesmo material de construção (bambu - Guadua augustifolia, Guadua chacoensis e Dendrocalamus giganteus, entre outros). Mediante certo cuidado, a biomassa produzida nesses sistemas pode, provavelmente, ser utilizada como ração para animais e também como material para compostagem.

Sistemas de tratamento de água dotados de tratamento paisagístico são espaços multifuncionais híbridos entre paisagem e infraestrutura. Essas infraestruturas paisagísticas também são espaços inerentemente educativos já que ao explicitarem os benefícios proporcionados por mangues, alagados, brejos e demais áreas úmidas naturais colaboram com a conscientização acerca da importância da conservação desses ecossistemas. 


\section{REFERÊNCIAS BIBLIOGRÁFICAS}

AGÊNCIA NACIONAL DAS ÁGUAS. Panorama da Qualidade das Águas Superficiais do Brasil 2012. Brasília: ANA, 2012. Disponível em <http://www.ana.gov.br/ bibliotecavirtual/arquivos/20120625164216_Panorama_Portugues_Final.pdf>. Acessado em 30 de dezembro de 2012.

CHARMAN, Karen. A Sewer becomes a Water Park. 2003. Disponível em <http:// www.yesmagazine.org/issues/whose-water/karen-charman-a-sewer-becomes-a-water-park>. Acessado em 18 de março de 2013.

COELHO, Teixeira. A Cultura e o seu contrário. São Paulo: lluminuras: Itaú Cultural, 2008.

CONSELHO DE AVALIAÇÃO ECOSSISTÊMICA DO MILÊNIO. Ecossistemas e bemestar humano - Estrutura para uma avaliação. São Paulo: Editora Senac, 2005.

FERREIRA, José Carlos; MACHADO, João Reis. Infra-estruturas verdes para um futuro urbano sustentável: o contributo da estrutura ecológica e dos corredores verdes. Revista LABVERDE. n. 1, out. 2010, 68-90 p.

FRANCE, Robert L. Wetland Design - Principles and Practices for Landscape Architects and Land-Use Planners. New York: W.N. Norton, 2003.

FRANCO, Maria de Assunção Ribeiro. Desenho Ambiental - uma introdução à Arquitetura da paisagem com o paradigma ecológico. São Paulo: Annablume: FAPESP, 1997.

Planejamento Ambiental para a Cidade Sus-

tentável. São Paulo. Annablume: FAPESP, 2001.

HORN, Tamara Bianca. Integração de Sistemas Wetlands construídos + Fotoonização Catalítica no Tratamento de Efluentes de Campus Universitário. 2011. Dissertação. (Mestrado em Tecnologia Ambiental). Universidade de Santa Cruz do Sul.

IBGE. Indicadores de Desenvolvimento Sustentável - Brasil 2012. Rio de Janeiro: IBGE, 2012

IZEMBART, H; LE BOUDEC, B. Waterscapes - Using planting systems to treat wastewater. Barcelona: Gustavo Gili, 2003 
JOHN TODD ECOLOGICAL DESIGN. Client \& Case Study List: City of Fuzhou, Fujian Province, China - Urban Municipal Canal Restorer Fuzhou, China. Disponível em: < http://toddecological.com/PDFs/100623.casestudy.baima.pdf>. Acessado em 18 de março de 2013.

LOMBORG, B. O Ambientalista Cético - Revelando a Real Situação do Mundo. Rio de Janeiro: Elsevier, 2002.

ODUM, Eugene P. Ecologia. Rio de Janeiro: Editora Guanabara, 1988.

REBOUÇAS. Aldo da C. Água doce no mundo e no Brasil. In: REBOUÇAS, A.C.; Braga B.; Tundisi, J.G. (Orgs) Águas doces no Brasil: capital ecológico, uso e conservação. São Paulo: Escrituras, 2006.

RICKLEFS, R. E. A economia da natureza. Rio de Janeiro: Guanabara Koogan, 2011.

SVMA. Resíduos Sólidos - Cadernos de Educação Ambiental. Governo do Estado de São Paulo, 2010.

VAN KAICK, T. S. Estação de tratamento de esgoto por meio de zona de raízes: uma proposta de tecnologia apropriada para saneamento básico no litoral do Paraná. 2002. Dissertação. (Mestrado em Tecnologia). Centro Federal de Educação Tecnológica do Paraná.

ZANELLA, L. Plantas ornamentais no pós-tratamento de efluentes sanitários: wetlands-construídos utilizando brita e bambu como suporte. 2008. Tese. (Doutorado em Engenharia Civil, Saneamento e Ambiente). Universidade Estadual de Campinas

WWF. A Pegada Ecológica de São Paulo - Estado e Capital e a família de pegadas. WWF, 2012. 